\title{
Mycoplasma pirum sp. nov., a Terminal Structured Mollicute from Cell Cultures
}

\author{
RICHARD A. DEL GIUDICE, ${ }^{1 *}$ JOSEPH G. TULLY, ${ }^{2}$ DAVID L. ROSE, ${ }^{2}$ AND ROGER M. COLE ${ }^{3} \dagger$ \\ Diagnostic Microbiology Laboratory, National Cancer Institute-Frederick Cancer Research Facility, ${ }^{1}$ and Laboratory of \\ Molecular Microbiology, National Institute of Allergy and Infectious Diseases, ${ }^{2}$ Frederick, Maryland 21701 and \\ Laboratory of Streptococcal Diseases, National Institute of Allergy and Infectious Diseases, Bethesda, Maryland 20205 ${ }^{3}$
}

\begin{abstract}
More than 200 mycoplasma isolates recovered from a variety of contaminated cell cultures from 1968 to the present were found to belong to a distinct serological group (serogroup 38). An analysis of representative strains of this collection showed that they possessed all of the characteristics of organisms belonging to the genus Mycoplasma. These organisms were capable of fermenting glucose and of hydrolyzing arginine, and they required cholesterol or serum for growth. These organisms were unusual in that they possessed an organized terminal structure or tip, a morphological structure which has been found in at least six other species in the genus Mycoplasma. These organisms were also serologically distinct from all previously established species in the genus Mycoplasma and the genus Acholeplasma. On the basis of these findings and other morphological, biological, and serological characteristics of the strains recovered, we propose that mycoplasmas with these properties belong to a new species, Mycoplasma pirum sp. nov. Strain HRC 70-159 (= ATCC 25960) is the type strain of this species.
\end{abstract}

During a long-term program to systematically isolate and identify mycoplasma contaminants of cell cultures, we isolated a group of strains which had properties distinct from those of Mycoplasma species known to occur as contaminants of cell cultures. This collection of strains has been referred to as serogroup 38 (16). In May 1968, Mycoplasma sp. strain 8-065, the first recognized member of serogroup 38 , was isolated from a human tumor cell line designated SA3. During the 5 years after the first isolation, approximately 50 additional serologically related strains were isolated from a variety of cell lines, which were all obtained from the same laboratory. In 1973, serogroup 38 appeared in five additional laboratories; two of the laboratories had the organism present in the cell line SA3 which they were using, and the other three laboratories had recently received cell cultures from the laboratory in which cell line SA3 originated. To date, 237 strains of serogroup 38 have been isolated in 20 different laboratories. All 20 of these laboratories, with one possible exception, had exchanged cell cultures with one or more of the other laboratories or had received cell cultures directly from the laboratory from which the initial isolate was obtained. Because of the relatively narrow distribution of serogroup 38 in laboratories with a history of exchanging cell cultures, it is possible that all 237 isolates descended from a single strain. All attempts to determine the source of contamination have been unsuccessful. Although cell line SA3 was the first cell line in which serogroup 38 was detected, we cannot conclude that this was the first cell line to become infected or that the initial contamination occurred at the laboratory in question. Data on mycoplasma isolation from cell cultures are reported elsewhere (14a). Unlike all of the other Mycoplasma species known to occur as contaminants of cell cultures, the host or natural habitat of serogroup 38 strains is unknown, nor is there a demonstrable relationship between serogroup 38 strains and mycoplasmas isolated from natural sources. Aside from the fact that the organisms were serologically

\footnotetext{
* Corresponding author.

$\dagger$ Present address: 6200 Maiden Lane, Bethesda, MD 20014.
}

distinct from all previously established species in the genus Mycoplasma, the morphological characteristics of the strains, including a unique and organized terminal structure similar to that observed in only six other Mycoplasma species (22), provided additional stimulus to characterize these organisms. In this report we describe the basic properties of organisms belonging to serogroup 38 and propose that they be considered a new Mycoplasma species.

\section{MATERIALS AND METHODS}

Mycoplasmas, culture medium and cultivation techniques. Two Mycoplasma strains (strains HRC 70-159, [T = type strain] and FD 870) which were identified as belonging to and representative of serogroup 38 were selected for characterization. These strains and other early isolates were initially recovered on Edward medium (18), a formulation consisting essentially of heart infusion broth, fresh yeast extract, and $20 \%$ horse serum. A simplified medium (16) was used for the recovery of more recent isolates from cell cultures and for maintenance of organisms in the laboratory. The cultures were incubated at $37^{\circ} \mathrm{C}$. For solid growth medium, $0.8 \%$ (wt/vol) agarose was added to the Edward formulation; the inoculated media were incubated at $37^{\circ} \mathrm{C}$ under an anaerobic atmosphere (GasPak system; BBL Microbiology Systems, Cockeysville, Md.). Early passages of the isolates were also grown on broth media lacking penicillin and other antibiotics for at least five consecutive passages. At each subculture, the cultures were plated onto blood agar and incubated at $37^{\circ} \mathrm{C}$. After 2 to 4 days, the plates were examined for bacterial colonies.

Morphological studies. Broth cultures of the organisms were examined by dark-field microscopy. Cellular morphology was also assessed after Gram staining and observation by light microscopy. The ultrastructure of the organisms was also determined by electron microscopy. For negative staining, cultures in liquid media were pelleted by centrifugation at $12,000 \times g$ with an Eppendorf model 3200 centrifuge for $2.5 \mathrm{~min}$, suspended in residual broth or in $1 \%$ ammonium acetate, placed on coated grids, and stained with 1 to $2 \%$ ammonium molybdate, as previously described $(11,12,31)$. 
It was occasionally useful, before negative staining, to induce some cell disaggregation and gentle cell disruption by short exposures ( 0.5 to $3 \mathrm{~min}$ ) of the mycoplasma suspensions to mild sonication; suspensions in plastic Eppendorf centrifuge tubes were lowered into 0.5 in $(1.27 \mathrm{~cm})$ of water in an ultrasonic parts cleaner (Heat Systems Ultrasonics, Inc., Plainview, N.Y.) for the requisite time. Fluid cultures for sectioning were fixed initially by adding glutaraldehyde in $0.1 \mathrm{M}$ phosphate buffer ( $\mathrm{pH} 7.0$ ) to a final concentration of $2.5 \%$. After $2 \mathrm{~h}$ at room temperature, any adherent growth was scraped from the sides of the tube. The suspension was pelleted, washed, fixed secondarily in $1 \%$ osmium tetroxide, dehydrated, and embedded in Spurr medium, as previously described $(11,12,31)$. Silver sections cut with an LKB Ultratome III equipped with a diamond knife were stained with aqueous $1 \%$ uranyl acetate and Reynold lead citrate (12). Examination and photography were done with a Hitachi model HU-11C electron microscope operated at $74 \mathrm{kV}$.

Filtration studies. The filtration characteristics of strain HRC $70-159^{\mathrm{T}}$ were assessed by determining the number of viable cells in young (24- to 48-h-old), unfiltered broth cultures and in filtrates of these broth cultures after passage through a series of membrane filters having decreasing average pore sizes. Cellulose acetate membrane filters (Millipore Corp., Bedford, Mass.) with average pore sizes rated at $450,300,220$, and $100 \mathrm{~nm}$ were used. An unfiltered broth culture or each filtrate was inoculated $(0.2 \mathrm{ml})$ into $1.8-\mathrm{ml}$ volumes of broth containing $0.5 \%$ glucose and phenol red indicator. These suspensions were diluted serially ( 10 -fold) through at least nine vials. The vials were incubated at $37^{\circ} \mathrm{C}$, and the reciprocal of the terminal dilution showing a color change (from red to yellow) and moderate turbidity was taken as the number of viable mycoplasma cells in the sample, expressed as color-changing units per milliliter.

Tests for biological and biochemical properties. The procedures used to determine glucose fermentation, arginine hydrolysis, urea hydrolysis, phosphatase activity, tetrazolium reduction, serum liquefaction, and film and spot reactions have been described previously $(1,8)$. Hemadsorption of guinea pig erythrocytes to colonies of strain HRC $70-159^{\mathrm{T}}$ was assessed by a technique described previously (25).

Sterol requirement. The sterol requirements of strains HRC $70-159^{\mathrm{T}}$ and FD 870 were determined by a broth culture technique described previously (27).

Serological tests. Hyperimmune rabbit antisera were produced in the Mycoplasma Section, Laboratory of Molecular Microbiology, National Institute of Allergy and Infectious Diseases, as described previously (30). The production in equines and goats of antisera to some mycoplasmas and acholeplasmas has been described previously, and these reagents (National Institutes of Health reagents) are available from the Reference Reagent Program, National Institute of Allergy and Infectious Diseases (13). The antisera and type strains used for serological comparisons of strains HRC $70-159^{\mathrm{T}}$ and FD 870 are listed in Table 1. Colonies of the two organisms growing on agar were tested by both the disk growth inhibition technique (10) and the plate immunofluorescence procedure (17), using antisera and fluorescein-conjugated antisera, respectively, to the species listed in Table 1. The following two minor modifications were made to this sequence: the test with Mycoplasma agalactiae was performed only with the immunofluorescence procedure, since the antiserum for the growth inhibition test shows poor activity; and the reverse situation prevailed with the antiserum and conjugate to Acholeplasma parvum.

DNA base composition. The guanine-plus-cytosine composition of deoxyribonucleic acid (DNA) obtained from strain HRC $70-159^{\mathrm{T}}$ was determined by the buoyant density method of Schildkraut et al. (28). Preparations of DNAs from Mycoplasma arginini, Escherichia coli, and Clostridium perfringens were used as standards, and each DNA sample was tested in triplicate.

\section{RESULTS AND DISCUSSION}

Morphology and cultural properties. Broth cultures of strains HRC $70-159^{\mathrm{T}}$ and FD 870 examined by dark-field microscopy contained numerous pleomorphic, round, or coccobacillary forms. Preparations stained by the Gram technique exhibited gram-negative pleomorphic structures similar to those observed by dark-field microscopy. In electron microscopic studies, the strain HRC $70-159^{\mathrm{T}}$ cells were clearly flask shaped. This shape was often distorted, and the tip was bulbous in unfixed negatively stained preparations (Fig, 1A). In appropriate sagittal sections (Fig. 1B and $C$ ) the shape was obvious but more slender, and the single cytoplasmic membrane was clear. The overall length ranged from 0.54 to $0.64 \mu \mathrm{m}$, and the maximum width of the flask ranged from 0,17 to $0.33 \mu \mathrm{m}$. The length of the neck was 0.21 to $0.23 \mu \mathrm{m}$, and its width ranged from 0.08 to 0.13 $\mu \mathrm{m}$ at the base, tapering to 0.04 to $0.07 \mu \mathrm{m}$ at the tip. Like the necks of Mycoplasma pneumoniae (7), Mycoplasma alvi (19), Mycoplasma genitalium (31), and possibly other flaskshaped mycoplasmas (22), the neck of this organism contained a terminal structure or organelle. This was a densely staining fibrillar rod (usually broader or slightly forked at the base and only slightly shorter than the neck) that was surmounted at the tip by a dense caplike structure. Although not always apparent in sections, the cap was double, as demonstrated in negatively stained preparations. This appearance was best seen in termini isolated by sonication (Fig. 1D and E), where the fibrillar nature of the rod and a lucent area at its widened base were also constant features. Because of flattening, the dimensions of the organism and its terminal organelle were greater than the dimensions in sectioned material. A double cap has not been observed in similar preparations of the other flask-shaped mycoplasmas mentioned above (Cole, unpublished data). Optimal negatively stained preparations also showed a fine particulate 3-nm nap (Fig. 2A) that, unlike the naps of $M$. pneumoniae $(7,21)$ and $M$. genitalium $(31)$, was not restricted to the terminus but, instead, covered the entire surface of the mycoplasmal cell. Its presence, distribution, and probable polyanionic nature were indicated by ruthenium red staining (Fig. 2B) (24). In conventionally stained sections, the nap was not distinguishable from the outer lamella of the cytoplasmic membrane, but it may have contributed to the total apparent membrane width of 8.5 to $9 \mathrm{~nm}$.

Broth cultures of the two mycoplasma strains in Edward medium were slightly turbid after 5 days of incubation. In early broth cultures containing arginine and 0.1 to $0.5 \%$ glucose, a slight shift in $\mathrm{pH}$ toward the alkaline range was observed. This transient reaction was usually seen only in the bottom of the culture. Later, the broth cultures reverted to a stable acidic reaction indicative of metabolism of glucose. Colonies on agar medium had a classic fried-egg appearance after 4 to 7 days of incubation at $37^{\circ} \mathrm{C}$ under anaerobic conditions (GasPak system; BBL).

Reversion studies. Broth cultures of the mycoplasmas maintained in antibiotic-free medium for at least five pas- 
TABLE 1. Mycoplasma strains and antisera

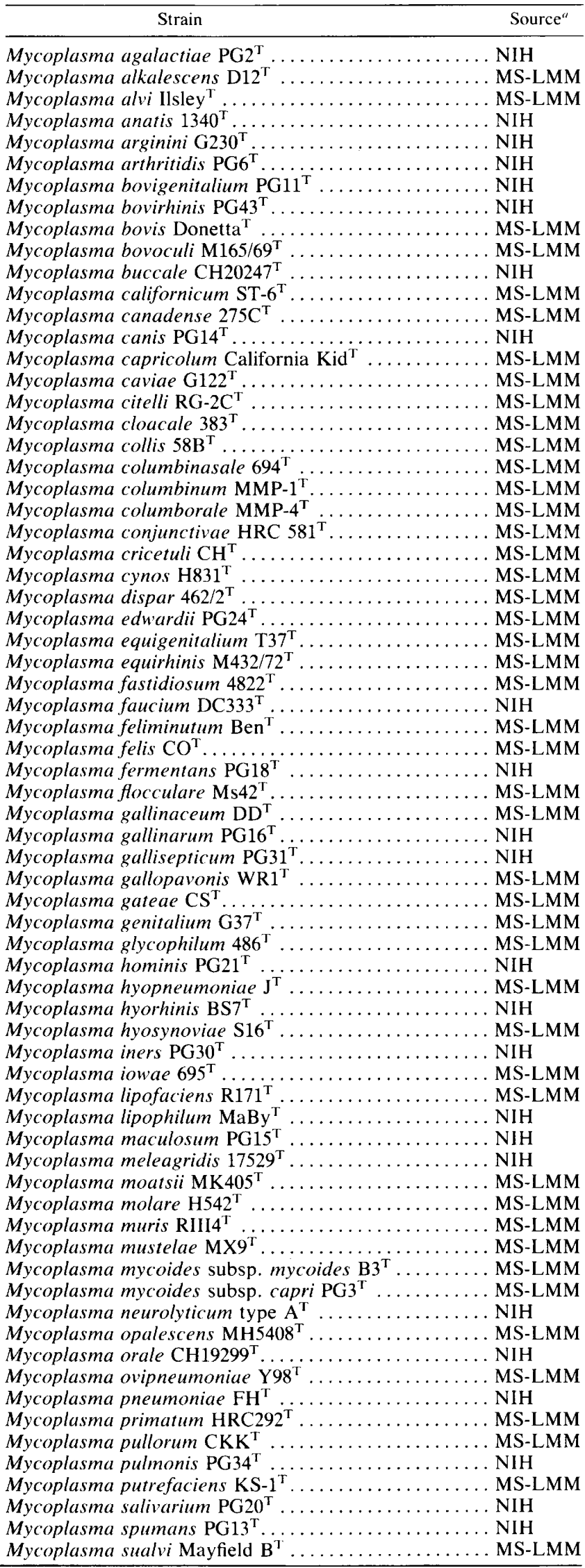

TABLE 1. - Continued

\begin{tabular}{|c|c|}
\hline Strain & Source" \\
\hline Mycoplasma subdolum $\mathrm{TB}^{\mathrm{T}}$. & MS-LMM \\
\hline Mycoplasma synoviae WVU $1853^{\mathrm{T}}$. & MS-LMM \\
\hline Mycoplasma verecundum $107^{\mathrm{T}} \ldots$ & MS-LMM \\
\hline Acholeplasma axanthum S-743 & MS-LMM \\
\hline Acholeplasma equifetale $\mathrm{C} 112^{\mathrm{T}}$. & MS-LMM \\
\hline Acholeplasma florum $\mathrm{L}^{\mathrm{T}} \ldots \ldots$ & MS-LMM \\
\hline Acholeplasma granularum $\mathrm{BTS} 39^{\mathrm{T}}$. & MS-LMM \\
\hline Acholeplasma hippikon $\mathrm{Cl}^{\mathrm{T}} \ldots \ldots$. & MS-LMM \\
\hline Acholeplasma laidlawii $\mathrm{PG}{ }^{\mathrm{T}}$.. & MS-LMM \\
\hline Acholeplasma modicum $\mathrm{PG} 49^{\mathrm{T}}$ & MS-LMM \\
\hline Acholeplasma morum $72-043^{\mathrm{T}}$. & MS-LMM \\
\hline Acholeplasma oculi $19 \mathrm{~L}^{\mathrm{T}} \ldots$ & MS-LMM \\
\hline Acholeplasma parvum $\mathrm{H}_{2} 3 \mathrm{M}^{\mathrm{T}}$. & MS-LMM \\
\hline
\end{tabular}

"NIH, National Institutes of Health reference reagent; MS-LMM, reagent prepared by Mycoplasma Section, Laboratory of Molecular Microbiology.

sages exhibited growth characteristics similar to those of strains grown in the presence of penicillin. There was no evidence of reversion to bacterial colonies when the strains were plated onto conventional bacteriological blood agar.

Filtration studies. The passage of broth cultures of strain HRC $70-159^{\mathrm{T}}$ through $450-\mathrm{nm}$ membrane filters did not reduce the viable cell titer $\left(10^{7}\right.$ color-changing units $\left./ \mathrm{ml}\right)$. Filtrates from $300-$ and $220-\mathrm{nm}$ membranes were reduced to $10^{6}$ and $10^{2}$ color-changing units $/ \mathrm{ml}$, respectively. No growth was detected in the filtrates from $100-\mathrm{nm}$ membranes.

Biochemical and biological properties. Both strain HRC $70-159^{\mathrm{T}}$ and strain FD 870 fermented glucose and hydrolyzed arginine. Colonies of strain HRC $70-159^{\mathrm{T}}$ failed to hemadsorb guinea pig erythrocytes or to produced cytopathogenic effects on cell cultures from which they were recovered. Additional biochemical and biological properties of this organism are summarized below.

Sterol requirement. The growth responses of strains HRC $70-159^{\mathrm{T}}$ and FD 870 to additions of cholesterol are shown in Table 2. Little growth was apparent in the base broth medium alone or when various fatty acid supplements or low levels of cholesterol ( 1 to $5 \mu \mathrm{g} / \mathrm{ml}$ ) were incorporated into the base medium. Significant growth occurred when higher quantities of cholesterol were supplied to the strains.

Serological tests. Growth inhibition and plate immunofluorescence tests, which was performed with antisera or conjugates prepared to the mycoplasmas and acholeplasmas listed in Table 1, indicated that strains HRC 70-159 and FD 870 were not related serologically to previously established species in the two genera. These strains were not tested against antisera to the four representatives of the genus Spiroplasma, since there was no morphological evidence of helical forms in these organisms. A slight one-way cross-reaction was observed in growth inhibition tests between the two tissue culture isolates and antiserum to $M$. alvi and $M$. genitalium. However, these reactions were not confirmed in plate immunofluorescence tests.

DNA base composition. The results of bouyant density experiments indicated that the DNA of strain HRC $70-159^{\mathrm{T}}$ has a guanine-plus-cytosine content of $25.5 \pm 1 \mathrm{~mol} \%$.

Another unusual characteristic of this cluster of tissue culture isolates, in addition to the unique terminal structure and morphology of the organism, is that these are the only Mycoplasma strains whose only known habitat is confined to cell cultures. All attempts to determine the natural habitat of this organism have been unsuccessful. This point should be underscored because of information published in review 

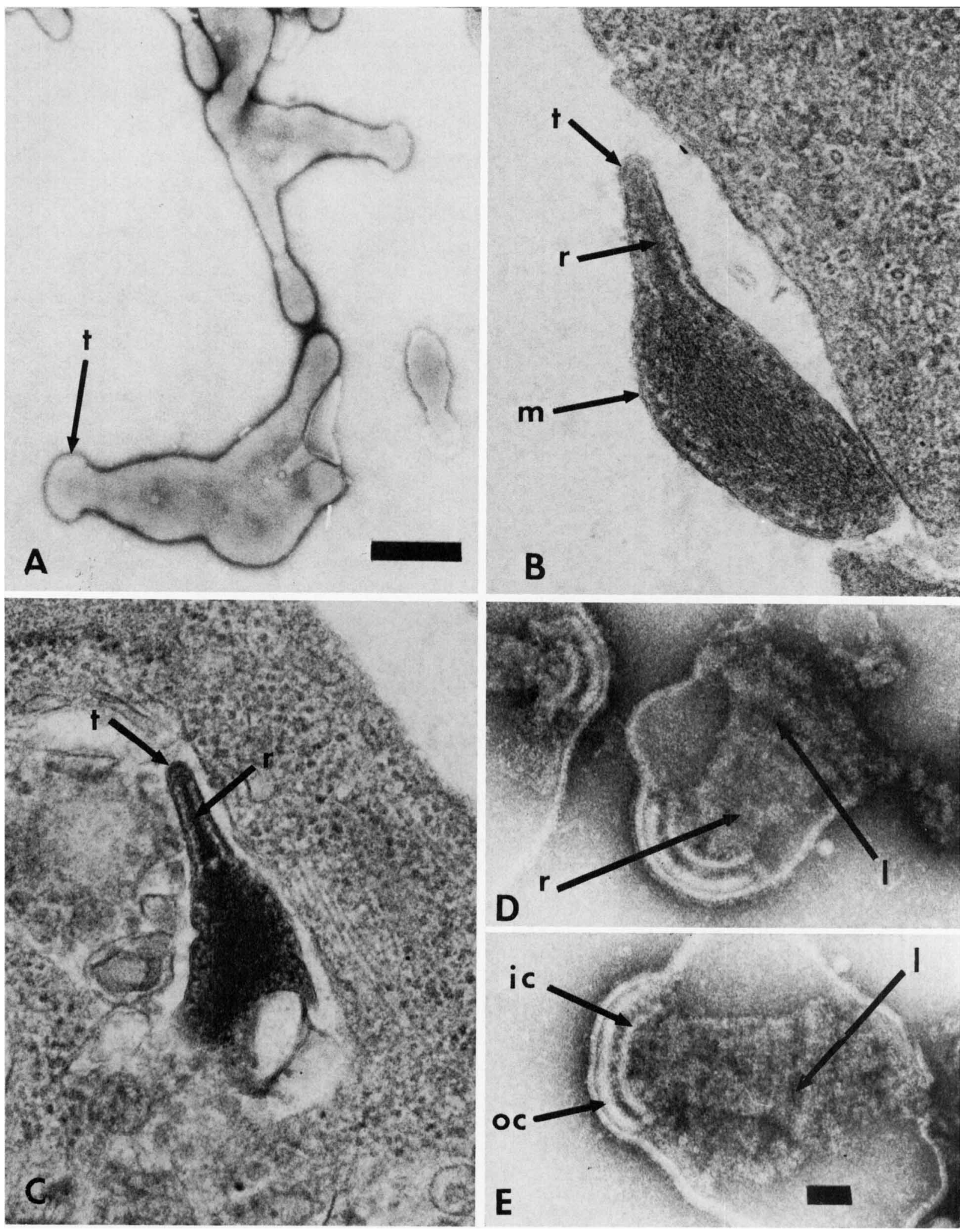

FIG. 1. Electron micrographs of strain HRC $70-159^{\mathrm{T}}$. (A) Unfixed negatively stained preparation, showing bulbous tips on cells. $\times 69,000$. (B and C) Sagittal section of a strain HRC 70-159 cell in an infected cell culture, showing the tip structure, terminal rod, and membrane. $\times 69,000$. (D and E) Negatively stained isolated termini, showing details of the cap structure. $\times 150,000 ; t$, Tip; $r$, rod; ic, inner cap; oc, outer cap; $\mathrm{m}$, membrane; l, lucent base area. Bar $=100 \mathrm{~nm}$. 

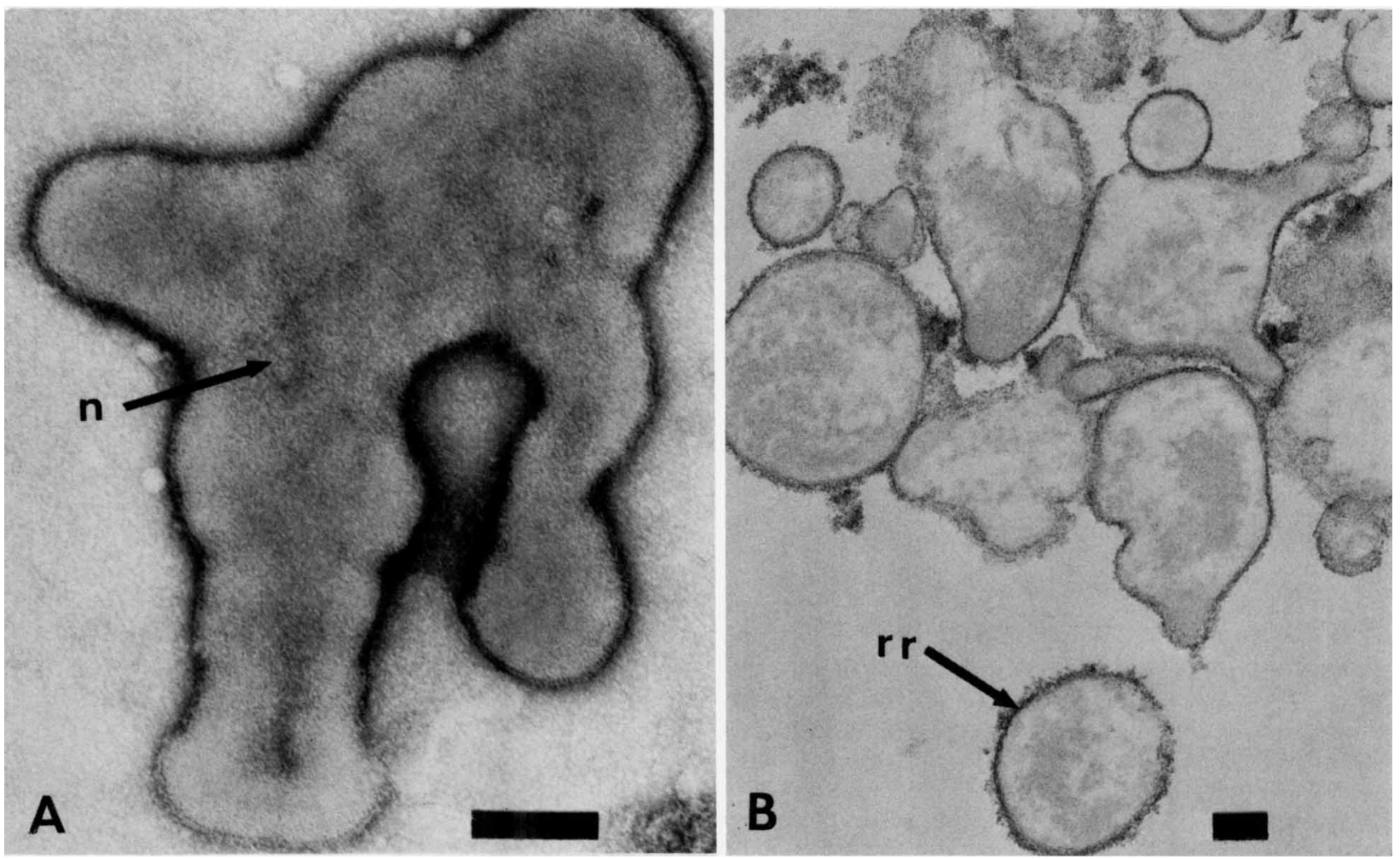

FIG. 2. Electron micrographs of strain HRC 70-159 $9^{\mathrm{T}}$. (A) Negatively stained preparation, showing the nap on the surface of a mycoplasma cell. $\times 150,000$. (B) Ruthenium red-stained organisms. $\times 69,000 . n, N a p ; r r$, ruthenium red deposit. Bar $=100 \mathrm{~nm}$.

articles (2-6) which indicated that this organism is of bovine origin. This impression was based on incorrect identification of three similar mycoplasma strains isolated from commercial bovine serum. The mistaken impression arose because antisera prepared in the laboratory of one of us (R.A.D.) by immunization of a goat with strain HRC 70-159 ${ }^{\mathrm{T}}$ reacted with strains of Mycoplasma bovis in immunofluorescence tests. This cross-reacting strain HRC $70-159^{\mathrm{T}}$ conjugate was included in a battery of reagents that were used in attempts to identify a number of mycoplasma strains that had been isolated from commercial bovine serum. Three of the strains reacted with the strain $\mathrm{HRC} 70-159^{\mathrm{T}}$ conjugate and were reported to belong to the strain HRC $70-159^{\mathrm{T}}$ complex (4). It was later determined (R. A. Del Giudice and M. F. Barile, unpublished data) that the three isolates were

TABLE 2. Growth responses of strains HRC $70-159^{\mathrm{T}}$ and FD 870 to cholesterol

\begin{tabular}{|c|c|c|c|}
\hline \multirow{2}{*}{$\begin{array}{l}\text { Supplement added to serum-free base } \\
\text { medium }\end{array}$} & \multirow{2}{*}{$\begin{array}{l}\text { Choles- } \\
\text { terol } \\
\text { concn } \\
(\mu \mathrm{g} / \mathrm{ml})\end{array}$} & \multicolumn{2}{|c|}{$\begin{array}{l}\text { Amt of protein } \\
(\mathrm{mg} / 100 \mathrm{ml})\end{array}$} \\
\hline & & $\begin{array}{c}\text { Strain } \\
\text { HRC } \\
70-159^{I}\end{array}$ & $\begin{array}{l}\text { Strain } \\
\text { FD } 870\end{array}$ \\
\hline $1 \%$ Bovine serum fraction & 0 & 3.98 & 3.66 \\
\hline No supplement & 0 & $1 \mathrm{G}^{\alpha}$ & IG \\
\hline $1 \%$ albumin, $0.01 \%$ Tween 80 , and 10 & 0 & 0.32 & 0.34 \\
\hline \multirow{4}{*}{$\mu \mathrm{g}$ of palmitic acid per $\mathrm{ml}$} & 1 & 0.32 & 0.35 \\
\hline & 5 & 0.45 & 0.46 \\
\hline & 10 & 1.17 & 1.09 \\
\hline & 20 & 1.09 & 1.03 \\
\hline
\end{tabular}

${ }^{a}$ IG, Insufficient growth for measurement. in fact strains of $M$. bovis. The observed immunofluorescence cross-reaction was unidirectional, in that conjugated $M$. bovis antiserum did not react with strain $\mathrm{HRC} 70-159^{\mathrm{T}}$. Furthermore, the one way cross-reaction was observed only in immunofluorescence tests; cross-reactions were not detected in growth inhibition or immunodiffusion tests (Del Giudice, unpublished data). It is not clear whether the one-way immunofluorescence cross-reaction represents a genuine antigenic relationship. Other antisera directed against strain HRC $70-159^{\mathrm{T}}$ (for example, the rabbit antisera used in the present study) showed no cross-reactions with $M$. bovis. Neither these observations nor the minor serological cross-reactions with $M$. alvi or $M$. genitalium represent serious problems to the distinct serological status of this cluster, since the DNA base compositions of these cross-reacting organisms differ significantly from those of serogroup 38 strains.

Serogroup 38 strains are relatively rare cell culture contaminants; they were found in less than $1 \%$ (237 isolates) of 34,697 cell cultures tested (14a). The rarity of serogroup 38 strains and the absence of comparable studies of a similar scale may account for the fact that workers in other laboratories have not described similar isolates. However, at the time that this paper was being prepared, we learned of the independent isolation of two tissue culture isolates that had the features of serogroup 38 strains (M. Salih, O. Vinther, and E. A. Freundt, personal communication). One strain (designated strain 1161-III) originated from a human testicular teratocarcinoma cell line, whereas the other strain (designated strain 13-15) was recovered from a cat colon carcinoma cell line. Both organisms degraded arginine and glucose and possessed a polar terminal structure. Subsequent serological tests performed on these two strains with 
antiserum to strain HRC $70-159^{\mathrm{T}}$ confirmed a close serological relationship (E. A. Freundt, personal communication). In addition, Salih et al. also noted a one-way serological cross-reaction between strain $1161-$ III and $M$. alvi, similar to our experiences. However, DNA-DNA hybridization tests between strain 1161-III and both $M$. alvi and Mycoplasma sualvi did not show any genetic relationship among these three mycoplasmas (9).

However, the lack of other reports on the occurrence of these organisms may not be fully indicative of whether similar mycoplasmas have been observed previously. Electron micrographs of a mycoplasma strain isolated from a cell line designated ESP-1 were published by de Harven (14); this strain, which de Harven described as "pear shaped," is similar in morphology to serogroup 38 strains. This similar morphology, which is unique among mycoplasmas that contaminate cell cultures, along with the fact that we have isolated serogroup 38 strains from other cultures of cell line ESP-1, suggests that the strain described by de Harven may be a member of the strain HRC $70-159^{\mathrm{T}}$ species complex.

In two studies on the enzymatic activities of mycoplasmainfected cell cultures, the enzymes uracil phosphoribosyl transferase (23) and adenosine phosphorylase (20) were found in all mycoplasmas known to infect cell cultures except serogroup 38 strains. However, McGarrity and Carson (26) found that "Mycoplasma species 70-159" caused cytotoxicity to mammalian cell cultures in the presence of 6-methylpurine deoxyriboside. The mechanism of cytotoxicity is thought to be mediated by adenosine phosphorylase, so it is likely that this enzyme is present also in serogroup 38 strains, but the methods used for the detection of this enzyme in the first study (20) may not have been suitable.

Our evaluation of the properties of the organisms described above fulfills the essential criteria (29) for species of the class Mollicutes, including absence of cell walls, filterability, lack of reversion to bacterial forms with cell walls when grown in antibiotic-free media, penicillin resistance, and production of typical colonial forms on agar. The growth requirement of the strains for sterol and their morphology place these organisms in the family Mycoplasmataceae, and the inability of the organisms to hydrolyze urea indicates that they should be assigned to the genus Mycoplasma. In addition, the strains which we examined are serologically distinct from all previously established species in the genus Mycoplasma. We propose the name Mycoplasma pirum $\mathrm{sp}$. nov. for the organisms within this cluster of related strains. A taxonomic description is given below.

Mycoplasma pirum sp. nov. Mycoplasma pirum (pir'um. L. neut. $\mathrm{n}$. pirum pear, referring to the pear-shaped morphology of the cells). Cells are predominantly flask or pear shaped and possess an organized terminal structure. An outer, finely particulate nap (about $3 \mathrm{~nm}$ thick) covers the entire surface of the cell. Growth occurs in most conventional mycoplasma media. Colonies on solid medium under anaerobic conditions have a classic fried-egg appearance. The optimum temperature for growth appears to be $37^{\circ} \mathrm{C}$. The organisms produce acid from glucose and can also hydrolyze arginine. Urea is not hydrolyzed. Phosphatase, film and spot reaction, and gel liquefaction tests are negative. No hemadsorption of guinea pig erythrocytes occurs.

Serologically distinct from previously established $\mathrm{Myco}$ plasma species, as determined by growth inhibition and plate immunofluorescence tests. Pathogenicity unknown. Not cytopathogenic for cell cultures.
The habitat is not currently known. All strains of the organism have come from cell cultures.

The guanine-plus-cytosine content of the DNA is 25.5 mol\%, as determined by the buoyant density method.

Type strain: strain HRC 70-159 (= ATCC 25960).

\section{ACKNOWLEDGMENTS}

This research was supported in part by Public Health Service contract N01-C0-23910 with the National Cancer Institute.

We thank M. Gonda for help with electron microscopy and J. Derge for determining the guanine-plus-cytosine content.

\section{LITERATURE CITED}

1. Aluotto, B. B., R. G. Wittler, C. O. Williams, and J. E. Faber. 1970. Standardized bacteriologic techniques for the characterization of Mycoplasma species. Int. J. Syst. Bacteriol. 20:35-58.

2. Barile, M. F. 1973. Mycoplasmal contamination of cell cultures: mycoplasma-virus-cell culture interactions, p. 131-172. In J. Fogh (ed.), Contamination of cell cultures. Academic Press, Inc., New York.

3. Barile, M. F. 1979. Mycoplasma-tissue cell interactions, p. 425-474. In J. G. Tully and R. F. Whitcomb (ed.), The mycoplasmas, vol. 2. Human and animal mycoplasmas. Academic Press, Inc., New York.

4. Barile, M. F., and R. A. Del Giudice. 1972. Isolation of mycoplasmas and their rapid identification by plate epiimmunofluorescence, p. 165-181. In Ciba Foundation Symposium on Pathogenesis of Mycoplasma. Associated Scientific Publishers, Amsterdam.

5. Barile, M. F., H. E. Hopps, and M. W. Grabowski. 1978. Incidence and source of mycoplasma contamination: a brief review, p. 35-45. In G. J. McGarrity, D. G. Murphy, and W. W. Nichols (ed.), Mycoplasma infection of cell cultures. Plenum Press, New York.

6. Barile, M. F., H. E. Hopps, M. W. Grabowski, D. B. Riggs, and R. A. Del Giudice. 1973. The identification and sources of mycoplasmas isolated from contaminated cell cultures. Ann. N.Y. Acad. Sci. 225: 251-264.

7. Biberfeld, G., and P. Biberfeld. 1970. Ultrastructural features of Mycoplasma pneumoniae. J. Bacteriol. 102:855-861.

8. Bradbury, J. M. 1977. Rapid biochemical tests for characterization of Mycoplasmatales. J. Clin. Microbiol. 5:531-534.

9. Christiansen, G., G. Christiansen, and E. A. Freundt. 1985. Lack of genetic relatedness between Mycoplasma alvi and Mycoplasma sualvi. Int. J. Syst. Bacteriol. 35:210.

10. Clyde, W. A., Jr. 1964. Mycoplasma species identification based upon growth inhibition by specific antisera. J. Immunol. 92:958-963.

11. Cole, R. M. 1983. Transmission electron microscopy: basic techniques, p. 43-50. In S. Razin and J. G. Tully (ed.), Methods in mycoplasmology, vol. 1. Academic Press, Inc., New York.

12. Cole, R. M., and T. J. Popkin. 1981. Electron microscopy and ultrastructure of bacteria, p. 34-51. In P. Gerhard (ed.), Manual of methods for general bacteriology. American Society for Microbiology, Washington, D.C.

13. Cunningham, S. (ed.). 1978. NIAID catalog of research reagents. Department of Health, Education and Welfare publication (NIH) 78-899. National Institutes of Health, Bethesda, Md.

14. de Harven, E. 1973. Identification of tissue culture contaminants by electron microscopy, p. 205-231. In J. Fogh (ed.), Contamination of cell cultures. Academic Press, Inc., New York.

14a.Del Giudice, R. A., and R. S. Gardella. 1984. Mycoplasma infection on cell culture: effects, incidence, and detection, $p$. 104-115. In vitro monograph no. 5. Use and standardization of vertebrate cell cultures. Tissue Culture Association, Gaithersburg, Md

15. Del Giudice, R. A., R. S. Gardella, and H. E. Hopps. 1980. Cultivation of formerly noncultivable strains of Mycoplasma hyorhinis. Curr. Microbiol. 4:75-80.

16. Del Giudice, R. A., and H. E. Hopps. 1978. Microbiological methods and fluorescent microscopy for the direct demonstra- 
tion of mycoplasma infection of cell cultures, p. 67-69. In G. J. McGarrity, D. G. Murphy, and W. W. Nichols (ed.), Mycoplasma infection of cell cultures. Plenum Press, New York.

17. Del Giudice, R. A., N. F. Robillard, and T. R. Carski. 1976. Immunofluorescence identification of mycoplasma on agar by use of incident illumination. J. Bacteriol. 93:1205-1209.

18. Edward, D. G. ff. 1947. A selective medium for pleuropneumonia-like organisms. J. Gen. Microbiol. 1:238-243.

19. Gourlay, R. N., S. G. Wyld, and R. H. Leach. 1977. Mycoplasma alvi, a new species from the bovine intestinal and urogenital tracts. Int. J. Syst. Bacteriol. 27:89-96.

20. Hatanaka, M., R. A. Del Giudice, and C. Long. 1975. Adenine formation from adenosine by mycoplasmas: adenosine phosphorylase activity. Proc. Natl. Acad. Sci. U.S.A. 72:1401-1405.

21. Hu, P. C., R. M. Cole, Y. S. Huang, J. A. Graham, D. E. Gardner, A. M. Collier, and W. A. Clyde, Jr. 1982. Mycoplasma pneumoniae infection: role of a surface protein in the attachment organelle. Science 216:313-315,

22. Kirchhoff, H., R. Rosengarten, W. Lotz, M. Fischer, and D. Lopatta. 1984. Flask-shaped mycoplasmas: properties and pathogenicity for man and animals. Isr. J. Med. Sci. 20:848-853.

23. Long, C. W., R. A. Del Giudice, R. S. Gardella, and M. Hatanaka. 1977. Uracil phosphoribosyl transferase activity of mycoplasma and infected cell cultures. In Vitro 13:429-433.
24. Luft, J. H. 1971. Ruthenium red and violet. I. Chemistry, purification, methods of use for electron microscopy and mechanism of action. Anat. Rec. 171:347-368.

25. Manchee, R. J., and D. Taylor-Robinson. 1969. Utilization of neuraminic acid receptors for mycoplasmas. J. Bacteriol. 98: 914-919.

26. McGarrity, G. J., and D. A. Carson. 1982. Adenosine phosphorylase-mediated nucleoside toxicity. Exp. Cell Res. 139: 199-205.

27. Razin, S., and J. G. Tully. 1970. Cholesterol requirement of mycoplasmas. J. Bacteriol. 107:306-310.

28. Schildkraut, C. L., J. Marmur, and P. Doty. 1962. Determination of the base composition of deoxyribonucleic acid from its buoyant density in $\mathrm{CaCl}$. J. Mol. Biol. 4:430-433.

29. Subcommittee on the Taxonomy of Mollicutes. 1979. Proposal of minimal standards for descriptions of new species of the class Mollicutes. Int. J. Syst. Bacteriol. 29:172-180.

30. Tully, J. G., M. F. Barile, D. G. ff. Edward, T. S. Theodore, and H. Ernø. 1974. Characterization of some caprine mycoplasmas, with proposals for new species, Mycoplasma capricolum and Mycoplasma putrefaciens. J. Gen. Microbiol. 85:102-120.

31. Tully, J. G., D. Taylor-Robinson, D. L. Rose, R. M. Cole, and J. M. Bove. 1983. Mycoplasma genitalium, a new species from the human urogenital tract. Int. J. Syst. Bacteriol. 33:387-396. 